\title{
STRATEGY FOR THE MARKETING OF THE PREMIUM SERVICE OF THE PLAYA PESQUERO RESORT HOTEL
}

\author{
José L. Figueiras Rodríguez \\ Hotel Playa Pesquero \\ Rafael Freyre, Holguín, Cuba \\ jefe.riesgos@ppesquero.co.cu
}

\author{
Migdely Barbarita Ochoa Avila \\ Faculty of Business Sciences, University of Holguin \\ Holguín, Holguín, Cuba \\ migdely@uho.edu.cu
}

\author{
Justa Medina Labrada \\ Faculty of Business Sciences, University of Holguin \\ Holguín, Holguín, Cuba \\ imedina@uho.edu.cu
}

Reception Date: 02/28/2019 - Approval Date: 05/09/2019

\begin{abstract}
Marketing luxury hotels is relevant to meet the growing demands of customers, in this, the Premium services are essential to maintain the planned revenue. The research defined as scientific problem the following: The insufficient commercialization from the strategic of the Premium service, limits the income of this service in the hotel Playa Pesquero. The general objective was to: Develop a strategy for the marketing of the Premium service, which contributes to increasing the income of this service in the Playa Pesquero hotel. Several theoretical methods were used, such as analysis and synthesis, inductivedeductive, structural systemic, and among the empirical ones: scientific observation, interview, review of documents and the criterion of specialists. The strategy for marketing the Premium service was structured in four essential components: objectives, phases, tasks, and techniques to be employed. The partial application of the strategy has achieved among its results the following: design of the profile of target markets: Canada, United Kingdom, Germany and Italy; the updating of strategic objectives; the design of the product, price, distribution and promotion strategies; and an action plan based on the strategies outlined, all of which contributed to the increase of the total revenues of the Premium service.
\end{abstract}

KEY WORDS: Marketing in luxury hotels; Strategy; Premium service.

“Visión de Futuro" Año 16, Volumen No 23 No2, Julio - Diciembre 2019 - Pág. 274 - 293 URL de la Revista: http://visiondefuturo.fce.unam.edu.ar/index.php/visiondefuturo/index URL del Documento: http://visiondefuturo.fce.unam.edu.ar/index.php/visiondefuturo/issue/view/ ISSN 1668 - 8708 - Versión en Línea 


\section{INTRODUCTION}

In the present, tourism in Cuba is open to the international to provide a destination that allows enriching the lives of customers through experiences that facilitate contact with the climate, geography, social and cultural reality, heritage and communities. The Cuban hotel industry is constantly growing and exhibits an annual capacity that is prepared to receive some 5.4 million visitors from all latitudes (Marrero, 2017).

In recent years the number of visitors has increased by 11.9 percent, and in 2017 it reached the figure of 4 million 700 thousand visitors, Cabrisas (2017) and Marrero (2017). Therefore, it is important to have a hotel that guarantees the quality established in its standard, and especially, better prepared to receive the luxury tourist, so demanding.

Holguín, as one of the most important tourist destinations in Cuba, has the only own brand premium service in the country, which is located in the Playa Pesquero hotel, one of the largest hotels built in Cuba since 2003. Given the relevance to continue the improvement of the marketing of the Premium service in this hotel, the present investigation was started at the beginning of 2016 based on the potential it has for its natural attractions near the sea and the high qualification of the human resources that work there, however, it has the following shortcomings:

- Limited decision making by the Commercial Department of the hotel in the promotion actions and the comarketing agreements, as well as little participation in tourism fairs, since these are planned and executed centrally by the Promotion and Sales Department of the Gaviota Tourism Group S.A.

- Insufficient publicity of the hotel and the Premium service within social networks such as: Facebook, Twitter, Google Plus and YouTube, and on Internet exchange sites among which stand out: TripAdvisor, Zoover, and TheHolidayCheck, which does not favors sales through the website of Gaviota S.A. (www.gaviotahotels.com) and other online platforms (IDISO, Booking.com).

- Low forecast in the marketing of the hotel in the first years of operation, which caused deficient occupancy and demanded to sell through upgrade offer prices directly in the hotel, which are lower than the contract prices.

- Lack of experience in the administration of this type of service that links sections called adults only with family hotels in the same resort.

In this research a strategy for the marketing of the Premium service is developed, which contributes to increase the income of this service in the Playa Pesquero hotel. The

\footnotetext{
"Visión de Futuro" Año 16, Volumen N²3 N², Julio - Diciembre 2019 - Pág. 274 - 293

URL de la Revista: http://visiondefuturo.fce.unam.edu.ar/index.php/visiondefuturo/index

URL del Documento: http://visiondefuturo.fce.unam.edu.ar/index.php/visiondefuturo/issue/view/16 
idea to defend is the following one: A strategy directed to the commercialization of the Premium service of the hotel Pesquero Beach, based on the per fil of the target markets; to provide tools for determining the potential of the product for those markets; and establish the scenarios and strategic objectives, increase the income of this service.

\section{DEVELOPMENT}

\section{Premium services in luxury hotels}

Before tackling the fundamental characteristics of Premium services, it is necessary to approach luxury hotels, which are hospitality companies that have a very old tradition rooted in the old continent. They are characterized by offering the best service and widest range of services, including: space for swimming pools, shows and events almost every night, gym rooms with teachers and children's entertainers included, even a daycare service for children. They have a space for meals and evenings with live music, as well as a menu developed by several chefs specialized in the gastronomy of the region Guiñazu (2016), Harmon (2016), Larraiza (2017), Ruz (2017), and Layman (2017).

Premium services stand out among luxury services. Pérez and Merino (2015) stated that Premium is an adjective that is used to qualify a service or a product with special characteristics, of superior quality to the average. The usual thing is that the Premium is a privilege destined to those consumers who pay an additional amount.

It is an elitist product, with a high level of functionality and reliability, thanks to an exquisite design; characteristics that must be added, in addition, a premium price. Therefore, these products are directed publicly to a target public of high class, wealthy, of great purchasing power. Premium customers are rational buyers who value the quality, functionality, design of the item and, here lies the main difference, which has an excellent value for money, otherwise, they will not make the purchase. A Premium product / service is at the end of the differentiation strategy, since it offers a better product at a substantially higher price.

Guerrero (2014) details seven keys to identify a Premium product or service, these are:

1. It is innovative: its talents are in the constant search for differentiation. Because they are trendsetters, they face an insistent perception of their competitors.

2. The service is limited: this happens for market reasons. The market may be relatively small or the preferences of this niche differ greatly from the rest. 
3. Has tradition: The hotel has a history of tradition and constant search for quality. This story is the backing in which consumers place their trust.

4. Quality comes before the price.

5. Exceed the expectations of its customers: Its consumption causes pleasant surprises, an extra value, an unexpected addition, a spectacular service. In this way the consumption process is as pleasant as the purchase and its memory. The product translates into a special experience and an unforgettable experience.

6. Proposes or inserts a vision of the exclusive and improved world of reality: What is transmuted into a system of objects that lead this way of being to everyday experiences. A distinctive sphere of lifeis created within the everyday world that is for all.

7 It is visionary: It looks ahead to the future while keeping in mind its roots and traditions.

Premium refers to a particularity of a particular service, that which makes it stand out for its extreme quality and therefore only available for a small number of people.

In the Premium services, the trends in technology and tourism established by Córdova (2016), De Miguel (2016), and Miralles (2016) are followed: Online market, highly competitive and complex; New business models; and Big data and marketing. This means that the trends that luxury customers follow are related to the global trends in information technology and communications, which highlights the importance of the flow of promotional information and innovation in online marketing.

\section{Methodologies and procedures for formulating commercial strategies}

There are various proposals at the theoretical level for the preparation of marketing plans, used interchangeably according to the complexity of the study and the organization in which it is applied (Figueiras, 2018). In the Cuban context, the strategic management model that contributes to achieve the integration of strategic, tactical and operational levels in organizations with a view to increasing their performance is implemented. In this regard, it highlights research findings from I to $s$ found:

-Palau (2001): Procedure for the preparation of a marketing plan for a tourist destination.

-Peña (2006): Procedure to position the destination Holguin in the issuing markets that visit it.

\footnotetext{
“Visión de Futuro" Año 16, Volumen No 23 N², Julio - Diciembre 2019 - Pág. 274 - 293 URL de la Revista: http://visiondefuturo.fce.unam.edu.ar/index.php/visiondefuturo/index URL del Documento: http://visiondefuturo.fce.unam.edu.ar/index.php/visiondefuturo/issue/view/16 
-Cardet (2007): Model on strategy design in the area of science and technological innovation.

-Rivero (2008): Procedure for the commercial management of a tourist destination. -Rodríguez (2008): Methodology for strategic planning in the commercial area.

-Hernández (2010): Procedure for the elaboration and implementation of the marketing plan in small and medium-sized hotels of transit of the destination Villa Clara.

- Escalona (2010): Procedure for the formulation of strategies for a destination issuing market.

- Medina (2012): Procedure for the formulation of commercial strategies of a tourist destination for an issuing market.

The above proposals have in common the fulfillment of several of the basics of strategic planning process, is or $\mathrm{s}$ are the internal and external diagnosis, the definition of the mission and vision, the use of the matrix Weaknesses - Threats - Strengths - Opportunities (SWOT), determining the strategic objectives and the formulation and implementation strategies. Of these, it is considered that the procedure contributed by Medina (2012) collects the best previous experience in accordance with the objective of this research, and incorporates an element of vital importance: defining the profile of the target markets in the that includes the elements that ensure a broad characterization of them, an aspect that is considered essential for the effective formulation of commercial strategies in order to satisfy those markets.

Considering that the present investigation conceived as a practical field the marketing of the Premium service in the Playa Pesquero hotel, it was necessary to analyze in depth the scope of some steps and techniques proposed by Medina (2012), because they do not conform specifically to the characteristics of a service as peculiar as the Premium and with different target markets.

By way of synthesis, it is considered that the development of commercial strategies is necessary to conceive it in phases with the same level of importance, ranging from: the phase of strategic analysis, which must include the selection of a competent team of specialists, the elaboration of the profile of the target markets and the determination of the potential of the product for those markets, it is also relevant the determination of the scenarios and of the key factors of the success; the strategic formulation phase that should include the determination of arrival and income projections, the strategic objectives, the formulation of price, product, distribution and promotion strategies, and the evaluation of the 
factors that limit the implementation of these strategies; and finally, the strategic evaluation phase, which must contain the control of the strategies, the evaluation of established indicators and the communication of the results achieved. All of the above contributes to a better conception of the marketing of the Premium service in luxury hotels.

\section{Strategy for the marketing of the Premium service at the Playa Pesquero hotel}

The general objective of the strategy is to promote the commercialization of the Playa Pesquero hotel's Premium service, based on: the preparation of the profile of the target markets, determination of the potential of the product for those markets, as well as the determination of the scenarios and strategic objectives for the design of the product, price, distribution and promotion strategies, and their control, in order to increase the income in this service.

The proposed strategy is structured into four essential components through which the process of marketing the Premium service of the Playa Pesquero hotel takes place, these are: objectives, phases, tasks, and techniques to be employed. The representation of the analysis structure to be followed for the marketing of the Premium service is shown in Figure $N^{\circ} 1$.

\footnotetext{
"Visión de Futuro" Año 16, Volumen No 23 N², Julio - Diciembre 2019 - Pág. 274 - 293

URL de la Revista: http://visiondefuturo.fce.unam.edu.ar/index.php/visiondefuturo/index

URL del Documento: http://visiondefuturo.fce.unam.edu.ar/index.php/visiondefuturo/issue/view/16

ISSN 1668 - 8708 - Versión en Línea

E-mail: revistacientifica@fce.unam.edu.ar
} 


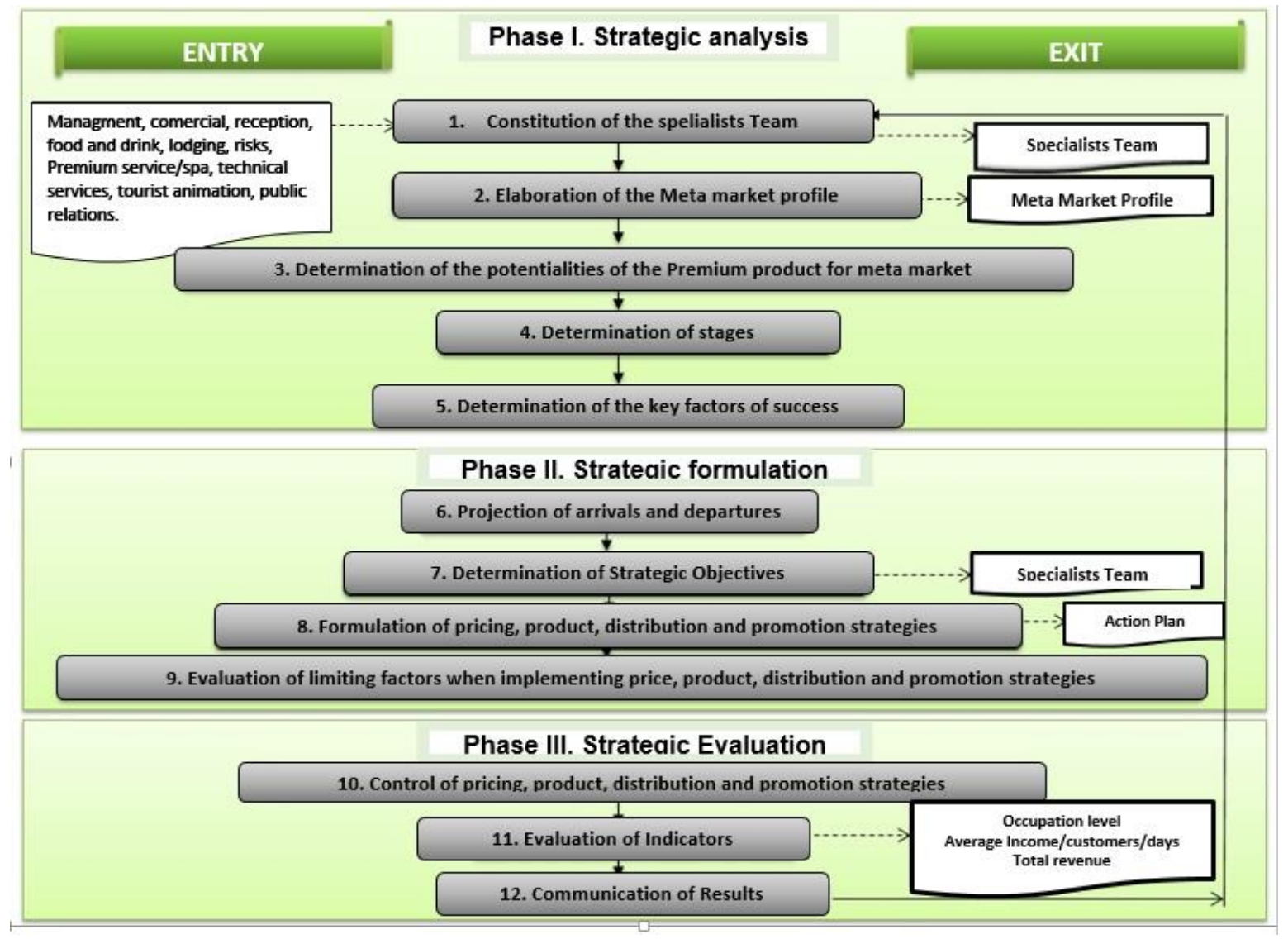

Figure $\mathbf{N}^{\circ}$. Graphic representation of the structure to follow for the marketing of the Premium service of the Playa Pesquero hotel

Source: Own Elaboration

The phases of the strategy are described below:

Phase I. Strategic analysis

Task 1. Constitution of the team of specialists

A team of ten specialists was formed representative of the charges related to the Premium service (management, commercial, reception, food and drink $(A+B)$, accommodation, risks, Premium / spa service, technical services, tourist animation and public relations). In this composition are: two masters in tourism management with experience in the hotel operation, three commercial specialists with more than eight years of experience, a senior service manager, two hotel managers, a reserve area specialist and another from the gastronomic service area. The commercial specialist was selected as responsible for the team. They were thaught by risk specialist two training on trends in marketing luxury hotels, which were developed at the hotel in the first half of 2017 and were very useful to analyze the peculiarities of the premium service, its potential and challenges Task 2. Elaboration of the profile of the target markets 
To elaborate the profile of the target markets, the importance of studying the variables of the tourist profiles established by Medina (2012), Beauchamp and Barnes (2015) and De la Mora (2017) must be taken into account. According to the commercial policy of Grupo Gaviota SA, the main target markets in Cuba are: Canada, United Kingdom, Germany and Italy. A synthesis of the profile of Canada is shown below:

-Consumer behavior: Currently he is more interested in the quality of the product, its origin, composition and price, especially since the global financial crisis of 2009. It is also excessively sensitive to advertising and tends to buy fashion products. In contrast to recent years, consumer confidence has strengthened thanks to the rebound in the economy. Canadian consumers demand a high-quality sales and after-sales service. It is extremely useful to offer a free telephone service to maintain contact with consumers. Canadian consumers are increasingly sensitive to problems related to the environment and excessive consumption, and increasingly use the Internet for their purchases: in the last decade Internet sales have grown at a faster rate than sales in the United States. traditional shops (per capita spending on online purchases only increased by 17\% between 2015 and 2016, with a figure of 661 Canadian dollar is $\mathrm{s}(\mathrm{CAD})$ ). Younger consumers lead the growth of online shopping through the increasing use of smartphones and mobile devices when shopping online. The high value of housing has led young consumers away from the purchase of a property, which has generated a slower demand for different types of products for the home.

-Consumer profile and purchasing power: The standard of living in Canada is one of the highest in the world. Consumers trust that the employee will remain full, this stimulates consumption, at least in some provinces. There is a change in purchasing trends, especially among young Canadians. The main objectives of the majority of young people are to finish their studies, buy a house and have children. Middle-aged adults and those in the generation of the baby-boom (1946-1966) devote much time to leisure. Canadians care about their diet and do not hesitate to buy healthy, natural and organic products. It gives much importance to everything related to comfort and well-being. People aged 60 or older are the fastest growing segment of consumers. The population of Canada is one of the most diverse among modern Western countries, and this trend should continue in the coming years with the arrival of more immigrants. Increasingly, waves of immigrants influence the Canadian consumer profile and shopping habits, which modifies grocery purchases in particular. 
-Recourse to credit by consumers: In Canada, the use of credit by consumers is frequent. Between 2012 and 2017, consumer credit increased 2.5\% annually, which represented a total of 571.1 billion Canadian dollars (CAD). It is used to buy goods and services on credit and to finance purchases already made. The most common credit is the liquidity loan to finance purchases with terms (generally large items such as furniture or cars, but also to pay for gasoline and other perishable goods). Similarly, accumulated domestic debt, mortgages, collateral loans and other forms of non-personal consumer credit have increased at an annual rate of $1.8 \%$ in this five-year period. The debt has grown with a higher rate than the population, this causes a radical increase in debt levels per capita.

- Advertising media:

- Television: Television advertising is mainly concentrated in the population group from 35 to 49 years old. Much more effective than the isolated use of television is the combination of television, print advertising and the Internet, which increases the intention to purchase more than $47 \%$.

- Press: Print advertising still has a strong impact among the canisters, despite its decline in recent years, to make way for online advertising. However, the cost of traditional means of mass advertising, such as newspapers, is very high. The newspaper industry shows a decline at the level of spending, of 5.5\% in 2017 and 3\% in 2018. Therefore, the media plan strategies to move towards digital rather than printed media. Newspapers in 2017 represented $17 \%$ of total spending compared to $43 \%$ for digital support.

- Mail: In Canada, this type of advertising is known as Courrier Poubelle or Junk mail. The advertising brochures that are most conserved and appreciated are the weekly food and pharmaceutical products. When the children return to school, families pay special attention to the advertising brochures of clothing and school supplies.

- Means of transport: For many years advertising has invaded public transport, train stations and bus stops. The sale of outdoor advertising grew 3\% in 2017, largely thanks to a $13 \%$ increase in digital outdoor advertising in the year.

- Radio: Radio advertising is heard mostly in cars, offices and shops. Traditional mass advertising in Canada, like radio, has a high cost. Radio advertising is mostly local. In 2016-2017, sales of local radio advertising faced the steepest decline in five years. On the other hand, sales at the national level grew by $1.2 \%$ compared to the previous year.

\footnotetext{
"Visión de Futuro" Año 16, Volumen No 23 N², Julio - Diciembre 2019 - Pág. 274 - 293 URL de la Revista: http://visiondefuturo.fce.unam.edu.ar/index.php/visiondefuturo/index URL del Documento: http://visiondefuturo.fce.unam.edu.ar/index.php/visiondefuturo/issue/view/16 
-Web: Nearly 22 million Canadians use the Internet monthly. This network has become an irreplaceable means of communication, contact, search and purchase for consumers and businesses alike. Online advertising has a greater impact than television on the intention of Canadians to buy. Advertisers study consumers and invest an increasing share of their advertising budget in interactive media .Online advertising focuses mainly on the population aged 18 to 34 years. A crucial factor in promoting products and services is the creation and maintenance of a professional website. It was anticipated that the sale of advertising in social media would increase by $35 \%$, the sale of advertising in videos $20 \%$, and the sale of advertising in searches $13 \%$. As a whole, it was projected that the sale of digital advertising will increase by $16 \%$ in 2017, with a figure of 7 billion dollar e canadiens (CAD). The buying habits of Canadian consumers are also influenced by social media, and a growing number of them admit that they are influenced by reading reviews, comments and reactions on social media platforms, along with online ads. While local distributors traditionally lag behind US distributors in terms of their presence on the Internet, it is projected that in the coming years the growth of online purchases will be encouraged mainly by the increased presence on the Internet of these same local distributors.

Task 3. Determination of the potentialities of the Premium product for target markets

Through a group dynamic the team of specialists carried out the analysis of the SWOT Matrix, which is shown in the following table:

Table N¹. SWOT Analysis

\begin{tabular}{|l|l|}
\hline \multicolumn{1}{|c|}{ Opportunities } & \multicolumn{1}{c|}{ Threats } \\
O1. Discrete emission of visitors from the & T1. Fluctuations in exchange rates. \\
United States to Cuba and to the destination of & $\begin{array}{l}\text { T2. Increase in competition in the area with the } \\
\text { opening of the new lberostar hotel. }\end{array}$ \\
Holguin. & T3. Presence of the actual plant of the Rio de \\
O2. Growing importance given to the quality of & $\begin{array}{l}\text { Oro hotel in the destination. } \\
\text { services by customers. }\end{array}$ \\
O3. Entry of new airlines in the destination such & T4. Increased competition in the Caribbean with \\
as America Air-line and Copa Air-line that & high quality standards and lower prices. \\
operate with luxury market segments. & T5. Marked seasonality of occupation. \\
O4. Increase of a Thomas Cook flight. & A6. Irregularity in supplies \\
O5. Enhancement in the destination of market & A7 Little afluence to the destination of flights with \\
diversification such as: Southern Cone, Poland, & first class. \\
and Russia. & \\
\hline
\end{tabular}

\footnotetext{
“Visión de Futuro" Año 16, Volumen No 23 N², Julio - Diciembre 2019 - Pág. 274 - 293 URL de la Revista: http://visiondefuturo.fce.unam.edu.ar/index.php/visiondefuturo/index URL del Documento: http://visiondefuturo.fce.unam.edu.ar/index.php/visiondefuturo/issue/view/16 ISSN 1668 - 8708 - Versión en Línea 


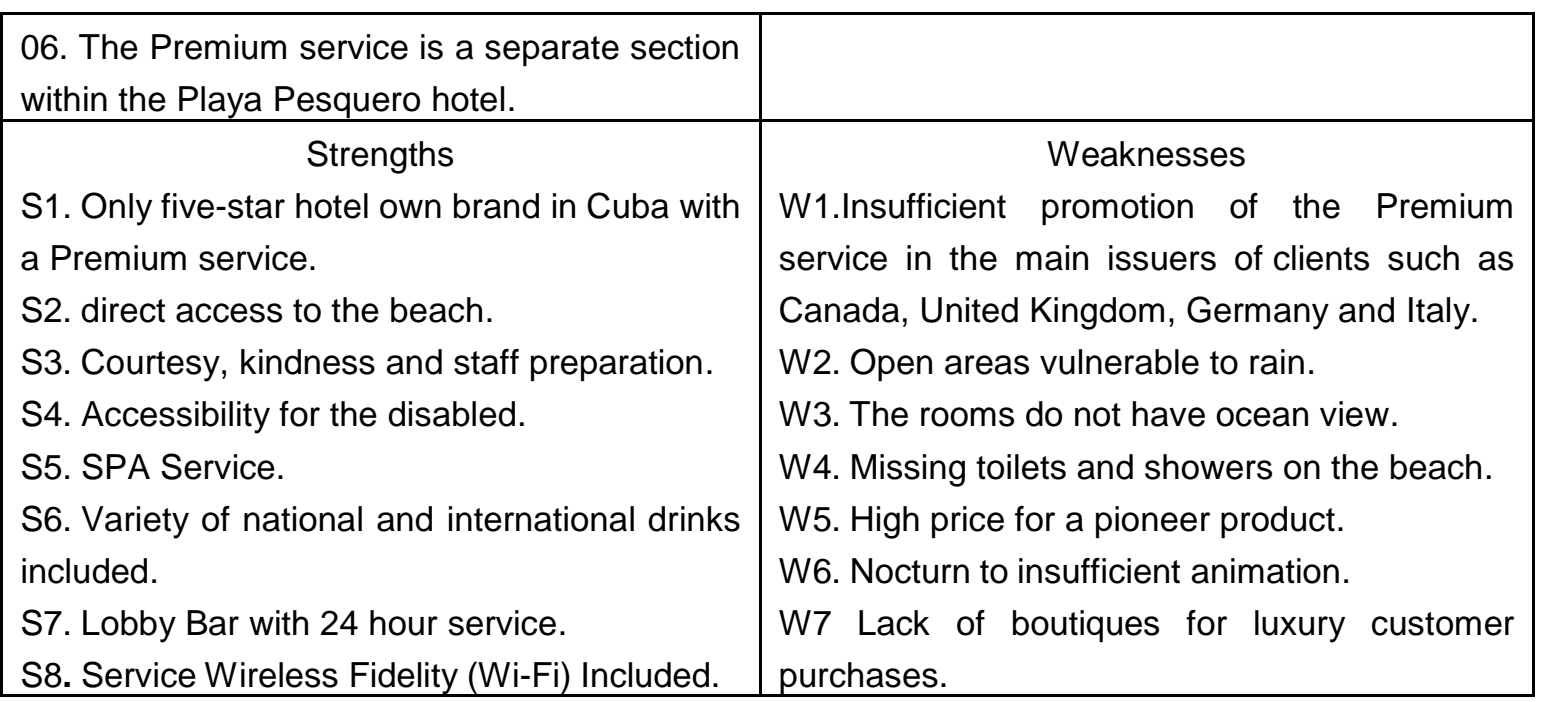

Source: Own Elaboration

Evaluation of external and internal factors: For the evaluation of the factors, the Internal Factor Evaluation Matrix (MEFI) and the External Factor Evaluation Matrix (MEFE) were used respectively. The result obtained when performing the MEFI is 2.23 below 2.50 , which indicates that in the Premium service the weaknesses over the strengths predominate, reason why it is in a disadvantageous position. In the case of the MEFE a value of 2.58 was obtained higher than 2.50 , therefore the opportunities over the threats predominate, which is considered an advantage for the hotel's Premium service.

Analysis of the SWOT Matrix: To perform the SWOT matrix, external and internal factors were reduced by leaving only the most important ones. The criterion of placing the opportunities and threats that have obtained 4 and 1 point respectively was used for this purpose, and the strengths and weaknesses with 4 and 1, respectively, on the left. Once the matrix was completed, it was concluded that the Premium service is in quadrant III (Weaknesses-Opportunities), so that opportunities must be taken advantage of to minimize existing threats in the environment.

The analysis of the SWOT matrix and the internal and external factors were presented to the board of directors for decision making. Then the team of specialists proceeded to determine the potentialities of the Premium service for target markets, these are:

- Natural: The Premium service is located on the north coast, on the Pesquero beach, in a rich natural environment within the Cristobal Colon Park and on the perimeter of one of the most important migratory bird corridors of the island.

- Infrastructure and available services: The Premium service has 56 rooms in an area of $93.68 \mathrm{~m}^{2}$ with a separate reception, lobby bar, reading room, gourmet restaurant for 
breakfast, lunch and dinner always a la carte, it also has a snack bar, pool, solarium, butler service and pool concierge, room service included with menu included 24 hours, Wi-Fi, pillow menu, $20 \%$ discount on laundry services, $15 \%$ discount on spa treatments, beats free check-out according to availability, superior amenities in the bathroom and access to all the facilities and reservations of the restaurants of the Playa Pesquero hotel.

- Cultural: Another attraction is undoubtedly the historical interest of the area, particularly Cayo Bariay, where the first encounter between European and aboriginal civilization took place; the Chorro de Maíta indocuban museum in the municipality of Banes, which offers the most important sample of pre-Columbian culture in the Antilles, as a main witness of the coexistence of both cultures, and the city of Holguín with important historical sites such as La Loma de la Cruz, the Periquera museum, among others.

- Offer: The nautical sports developed are the kayak, water bicycle and the catamaran, it has other offers such as: swimming with dolphins, the country day, the super countryside, Santiago de Cuba by bus, fishing rod, fishing with string, the sun cruise, among others.

- Training: Cu ate with 73 workers (25 in service, 17 in accommodation, 13 in kitchen area, 7 in reception, 6 butlers, 2 in hygiene, 2 in management and 1 in technical service). In the reception, service, and butler areas, workers dominate more than two idiosyncrasies. Those in the accommodation and cooking areas are graduates of the hotel and tourism school with relevant results, in addition to the advice of a foreign chef.

Task 4. Determination of scenarios

As a result of the application d construction method stage s of Vieytes (2010) three scenarios were determined, one of them was selected and middle stages: Characterized by the increase in scheduled and charter flights to the destination Holguin, by easing of the block or economic to Cuba by the United States, for international economic stability, for an increase in the promotional communication of the Playa Pesquero hotel's Premium service, for an adequate availability of communications technology and information in the product for the increase of competition in Cuba and the Caribbean, and a high perception by customers of the quality of the service they receive in the installation.

Task 5. Determining the key success factors

\footnotetext{
“Visión de Futuro" Año 16, Volumen No 23 №2, Julio - Diciembre 2019 - Pág. 274 - 293 URL de la Revista: http://visiondefuturo.fce.unam.edu.ar/index.php/visiondefuturo/index URL del Documento: http://visiondefuturo.fce.unam.edu.ar/index.php/visiondefuturo/issue/view/16 ISSN 1668 - 8708 - Versión en Línea 
To determine the key factors of success (FOS) the preferences of the Premium clients described in the profile were considered and a group dynamic was carried out to determine which of the elements defined in the profile are more influential in the increase of the arrivals to the Premium service, defining the following:

- FOS 1: Access to information on the attributes of the Premium service by tour operators and end customers.

- FOS 2: Exclusivity and quality of the service offered by the Premium service where they obtain a unique experience at any time.

- FOS 3: Possibility of exclusive offers.

Phase II. strategy formulation

Task 6. Projection of arrivals and income

To perform the screening Customer / day and income in Cuban Pesos Convertible (ICP) to 2021 operation was evaluated Premium from 2015 to 2017. This analysis allowed for the projection, which can be seen in I to the next table.

Table N². Customer Projection / Days and Income up to 2021

\begin{tabular}{|l|c|c|c|c|}
\hline \multicolumn{1}{|c|}{ Year } & 2018 & 2019 & 2020 & 2021 \\
\hline Customers/Days & 15000 & 17000 & 19000 & 21000.00 \\
\hline Income (ICP) & 1350.00 & 1615.00 & 1900.00 & 2205.00 \\
\hline
\end{tabular}

Source: Own Elaboration

Task 7. Determination of strategic objectives

To determine the objectives, the strategic marketing variables (segmentation, target market and positioning) for the market segment under study were designed, after which the strategic objectives for each of the key success factors were determined with a time horizon of up to 2021. Through group dynamics and team consensus, the strategic variables were defined as follows:

-Segmentation: Geographical, economic and organizational behavior variables were taken as criteria for segmentation.

-Target market: Tourists with vacation interests in beach hotels, with high purchasing power, from Canada, the United Kingdom, Germany and Italy.

\footnotetext{
“Visión de Futuro" Año 16, Volumen Nº 23 №2, Julio - Diciembre 2019 - Pág. 274 - 293 URL de la Revista: http://visiondefuturo.fce.unam.edu.ar/index.php/visiondefuturo/index URL del Documento: http://visiondefuturo.fce.unam.edu.ar/index.php/visiondefuturo/issue/view/16 
For these segments it is proposed that the Premium service work in the following positioning: Premium service of the Playa Pesquero hotel, characterized by the recognition of hotel excellence in the Caribbean and high levels of customer satisfaction. Then we proceeded to define the strategic objectives, these are:

-Objective $\mathrm{N}^{\circ} 1$ : Achieve an average annual occupation of $70 \%$ in the Premium service for 2021. The criteria for measuring this objective by years are shown in Fig. $\mathrm{N}^{\circ} 2$.

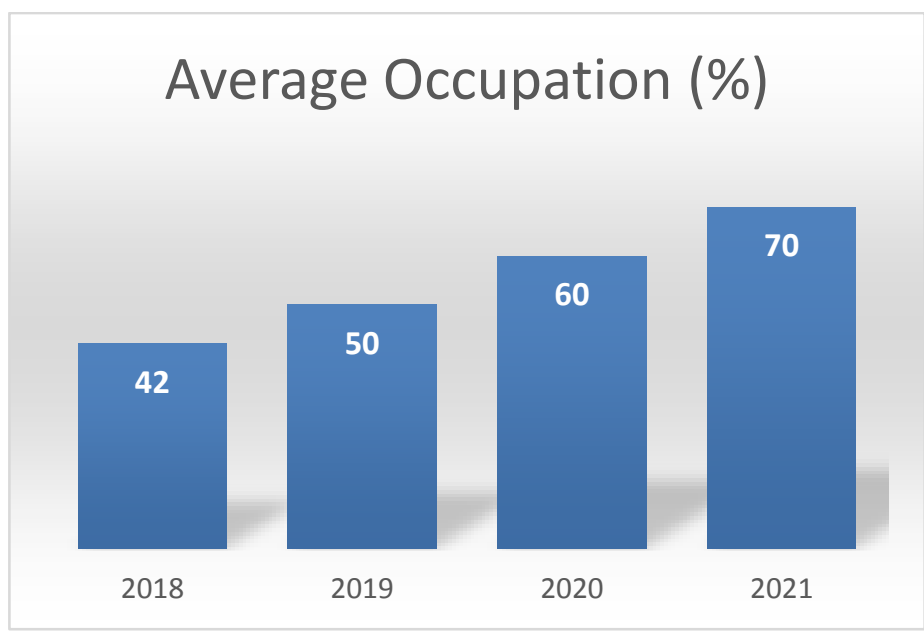

Figure $\mathrm{N}^{\circ}$ 2. Projection of the average occupation until 2021

Source: Own Elaboration

-Objective № 2: Reach an average income / Customers / Days of 105.00 CUC in 2021. The criteria for measuring this objective by years are shown in Fig. № 3 .

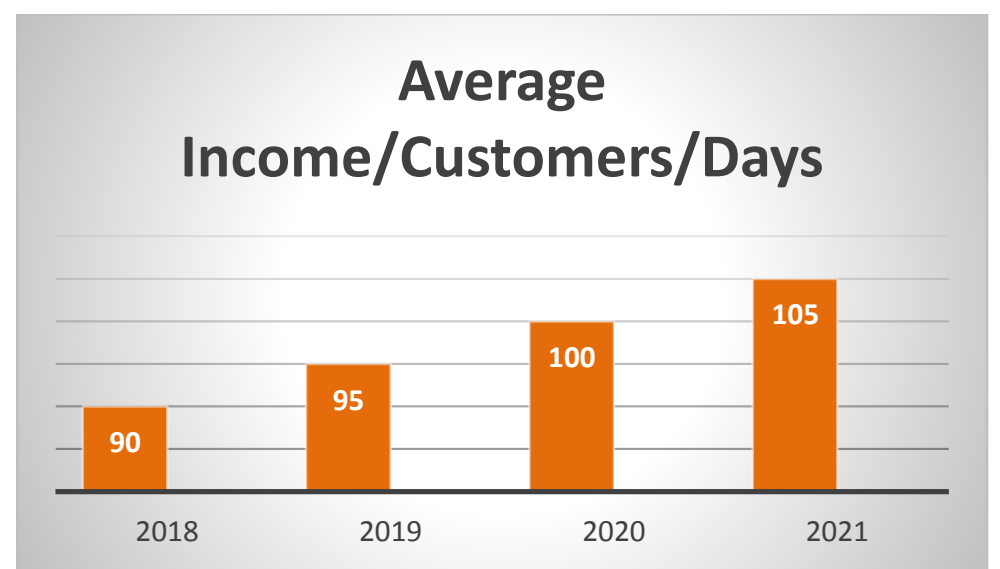

Figure $N^{\circ}$ 3. Average Income projection / Customers / Days until 2021

Source: Own Elaboration

Task 8. Formulation of pricing, product, distribution and promotion strategies

“Visión de Futuro" Año 16, Volumen No 23 №2, Julio - Diciembre 2019 - Pág. 274 - 293

URL de la Revista: http://visiondefuturo.fce.unam.edu.ar/index.php/visiondefuturo/index

URL del Documento: http://visiondefuturo.fce.unam.edu.ar/index.php/visiondefuturo/issue/view/16

ISSN 1668 - 8708 - Versión en Línea

E-mail: revistacientifica@fce.unam.edu.ar 
To meet the objectives set out above, a set of strategic lines was proposed, through the consensus of the team of specialists, these are:

1. Add values to the product in correspondence with its quality standard.

2. Establish and sell all year the Premium service with the contract prices with the tour operators.

3. Diversify product distribution channels.

4. Increase promotional communication of the product in the target markets.

5. Attract new customer segments from potential markets: Russia, Poland, Austria, Chile and the United States, as well as business customer segments, events and diplomats.

To fulfill the proposed objectives and in line with the strategic lines, an action plan was designed with 18 actions covering the operational variables of marketing (product, price, distribution, promotion) for the period 2017/2019.

Table $N^{\circ}$ 3. Action plan for the commercialization of the Premium service of the Playa Pesquero hotel

\begin{tabular}{|c|c|c|c|}
\hline Strategic line & Actions & Responsable & $\begin{array}{l}\text { Compliance } \\
\text { date }\end{array}$ \\
\hline \multirow{3}{*}{$\begin{array}{l}\text { Add values to the } \\
\text { product } \\
\text { correspondence in } \\
\text { with its quality } \\
\text { standard }\end{array}$} & $\begin{array}{l}\text { Train workers on current trends in } \\
\text { their specialization in } \\
\text { services }\end{array}$ & $\begin{array}{l}\text { Head of Human } \\
\text { Resources, } \\
\text { Chief Service } \\
\text { Premium }\end{array}$ & $\begin{array}{l}\text { I Semester } \\
2018\end{array}$ \\
\hline & $\begin{array}{l}\text { Guarantee new suppliers that ensure } \\
\text { the indispensable supplies to } \\
\text { guarantee the quality of this type of } \\
\text { service }\end{array}$ & \begin{tabular}{l|} 
Purchasing \\
Manager
\end{tabular} & $\begin{array}{l}\text { II } \\
\text { Semester } 2018\end{array}$ \\
\hline & $\begin{array}{l}\text { Incorporate the boutique store service } \\
\text { into the product }\end{array}$ & $\begin{array}{l}\text { Premium } \\
\text { service } \\
\text { manager }\end{array}$ & January 2019 \\
\hline \multirow{3}{*}{$\begin{array}{l}\text { Establish and sell all } \\
\text { year the Premium } \\
\text { service with the } \\
\text { contract prices with } \\
\text { the tour operators }\end{array}$} & $\begin{array}{l}\text { Make average cost card per client of } \\
\text { the Premium service }\end{array}$ & $\begin{array}{l}\text { Commercial } \\
\text { Manager, } \\
\text { Economic Chief }\end{array}$ & July 2018 \\
\hline & Conduct competitive price studies & $\begin{array}{l}\text { Commercial } \\
\text { boss }\end{array}$ & $\begin{array}{l}\text { II Semester of } \\
2018\end{array}$ \\
\hline & $\begin{array}{l}\text { Study and submit to Gaviota Group } \\
\text { S.A. stationary proposals and } \\
\text { promotional prices according to the } \\
\text { tempo roadsteads }\end{array}$ & $\begin{array}{l}\text { Commercial } \\
\text { boss }\end{array}$ & May 2018 \\
\hline $\begin{array}{lr}\text { Diversify } & \text { product } \\
\text { distribution } & \text { channels }\end{array}$ & $\begin{array}{l}\text { Create strategic alliances with new tour } \\
\text { operators and travel agencies that sell } \\
\text { packages to luxury clients such as: } \\
\text { Pegas Touristik, CIC Colombia, } \\
\text { Havanatur Chile and Argentina }\end{array}$ & $\begin{array}{l}\text { Commercial } \\
\text { boss }\end{array}$ & May 2018 \\
\hline
\end{tabular}

\footnotetext{
"Visión de Futuro" Año 16, Volumen No 23 N², Julio - Diciembre 2019 - Pág. 274 - 293 URL de la Revista: http://visiondefuturo.fce.unam.edu.ar/index.php/visiondefuturo/index URL del Documento: http://visiondefuturo.fce.unam.edu.ar/index.php/visiondefuturo/issue/view/16 ISSN 1668 - 8708 - Versión en Línea 


\begin{tabular}{|c|c|c|c|}
\hline Strategic line & Actions & Responsable & $\begin{array}{l}\text { Compliance } \\
\text { date }\end{array}$ \\
\hline & $\begin{array}{l}\text { Identify the airlines that connect the } \\
\text { target markets with the destination } \\
\text { Holguin }\end{array}$ & $\begin{array}{l}\text { Commercial } \\
\text { boss }\end{array}$ & April 2018 \\
\hline & $\begin{array}{l}\text { Expand the facilities for online sale of } \\
\text { the Premium product on the hotel } \\
\text { website }\end{array}$ & $\begin{array}{l}\text { Chief of } \\
\text { Commerce, } \\
\text { Chief } \\
\text { Economics }\end{array}$ & $\begin{array}{l}\text { II Semester } \\
2018\end{array}$ \\
\hline & $\begin{array}{l}\text { Create and apply mechanisms that } \\
\text { encourage tour operators to increase } \\
\text { premium service sales }\end{array}$ & $\begin{array}{l}\text { Commercial } \\
\text { boss }\end{array}$ & $\begin{array}{l}\text { II Semester } \\
2018\end{array}$ \\
\hline \multirow{4}{*}{$\begin{array}{l}\text { Increase } \\
\text { promotional } \\
\text { communication of } \\
\text { the product in the } \\
\text { target markets }\end{array}$} & $\begin{array}{l}\text { Design a specific catalog of the } \\
\text { Premium service for the sales network }\end{array}$ & $\begin{array}{l}\text { Commercial } \\
\text { boss }\end{array}$ & $\begin{array}{l}\text { II Semester } \\
2017\end{array}$ \\
\hline & $\begin{array}{l}\text { Update the attractions and offers of the } \\
\text { Premium service and the environment } \\
\text { on the hotel website through } \\
\text { interaction with customers }\end{array}$ & $\begin{array}{l}\text { Commercial } \\
\text { boss }\end{array}$ & 2018 Semester \\
\hline & $\begin{array}{l}\text { Audit the co-marketing actions in } \\
\text { search of greater effectiveness in } \\
\text { promotional communication actions }\end{array}$ & $\begin{array}{l}\text { Commercial } \\
\text { boss }\end{array}$ & $\begin{array}{l}\text { II Semester } \\
2018\end{array}$ \\
\hline & $\begin{array}{l}\text { Managing the online reputation of the } \\
\text { Premium service on the hotel website, } \\
\text { on the website of Gaviota S.A. and on } \\
\text { social networks (Tripadvisor, Zoover, } \\
\text { Monarc, Holidaycheck) }\end{array}$ & $\begin{array}{l}\text { Commercial } \\
\text { boss }\end{array}$ & $\begin{array}{l}\text { I Semester } \\
2018\end{array}$ \\
\hline \multirow{2}{*}{$\begin{array}{lr}\text { Capture } & \text { new } \\
\text { customer } & \text { segments } \\
\text { from } & \text { potential } \\
\text { markets: } & \text { Russia, } \\
\text { Poland, } & \text { Austria, } \\
\text { Chile and the United }\end{array}$} & $\begin{array}{l}\text { Carry out promotional communication } \\
\text { actions aimed at the segments Russia, } \\
\text { Poland, Austria, Chile and the United } \\
\text { States in the media where they are } \\
\text { reported }\end{array}$ & $\begin{array}{l}\text { Commercial } \\
\text { boss }\end{array}$ & $\begin{array}{l}\text { II Semester } \\
2018\end{array}$ \\
\hline & $\begin{array}{l}\text { Expand negotiations through MINTUR } \\
\text { with Russian tour operators }\end{array}$ & $\begin{array}{l}\text { Commercial } \\
\text { boss }\end{array}$ & $\begin{array}{l}\text { I Semester } \\
2018\end{array}$ \\
\hline \multirow{2}{*}{$\begin{array}{l}\text { States, as well } \\
\text { as business } \\
\text { customer segments, } \\
\text { events } \\
\text { diplomats }\end{array}$} & $\begin{array}{l}\text { Identify the sales network for luxury } \\
\text { clients in these segments }\end{array}$ & $\begin{array}{l}\text { Commercial } \\
\text { boss }\end{array}$ & $\begin{array}{l}\text { II Semester } \\
2018\end{array}$ \\
\hline & $\begin{array}{l}\text { Negotiate events with the entities } \\
\text { Suchel SA, Cervecería Bucanero, } \\
\text { SA, Telecommunications Company } \\
\text { (E TECSA ), among others }\end{array}$ & $\begin{array}{l}\text { Commercial } \\
\text { boss }\end{array}$ & $\begin{array}{l}\text { II Semester } \\
2018\end{array}$ \\
\hline
\end{tabular}

Source: Own Elaboration

Task 9. Evaluation of limiting factors when implementing pricing, product, distribution and promotion strategies

To assess the real possibilities of implementing the strategies, The diagnosis of the factors that could negatively affect them was made, for which the model Seven S McKinsey was used, as described by Stoner, Freeman and Gilbert (1996), whose results were:

- Structure: This allows developing strategies because the Premium service is an area within the hotel that interchanges with the rest of the general services. 
- System: The training and accounting systems in the hotel favor the proper functioning of the management systems in the service.

- Style: The National Directorate of the Gaviota S.A. Tourism Group and the hotel management are involved in obtaining superior results, and give priority to the strategies and their actions.

- Staff integration: The hotel's Management Board assesses the contribution of the staff to the fulfillment of the objectives of the Premium service, and as a consequence, seeks an adequate selection and training, both of the managers and of the service workers in general.

- Skills: The Premium service stands out and is recognized by the organization of events and dinners, distinguished by the quality of the services, by offering an inviting atmosphere, where the client can appreciate his stay in a very positive way. - Higher-order goals: Among them, we work in the achievement of being one of the main tourist destinations in Cuba and the Caribbean, which is differentiated by the peculiar combination of its natural and cultural attractions, with a diversified offer that allows us to satisfy its customers, by providing and developing a sustainable product. - Strategies: The Premium service managers have well-defined strategic objectives, which are attentive to compliance with the goals outlined in the short, medium and long term.

In line with the previous analysis and as a summary, the strategies can be applied until 2021 because of their flexible nature, and also because of the preparation of the work team in charge of its application, which has the competence to face some limitation, both internal and external, that may arise and influence the achievement of the objectives set.

Phase III. Strategic evaluation

Task 10. Control of price, product, distribution and promotion strategies

A total of 18 actions were proposed, of which 8 were fulfilled, for $44.44 \%$, these are:

1. Train workers on current trends of specialty services in Premium.

2. Make average cost card per customer of the Premium service.

3. Create strategic alliances with new tour operators and travel agencies that sell packages to luxury clients such as: Pegas Touristik, CIC Colombia, Havanatur Chile and Argentina.

4. Identify the airlines that connect the target markets with the destination Holguin.

5. Design a specific catalog of the Premium service for the sales network.

\footnotetext{
"Visión de Futuro" Año 16, Volumen No 23 N², Julio - Diciembre 2019 - Pág. 274 - 293 URL de la Revista: http://visiondefuturo.fce.unam.edu.ar/index.php/visiondefuturo/index URL del Documento: http://visiondefuturo.fce.unam.edu.ar/index.php/visiondefuturo/issue/view/16 
6. Update the attractions and offers of the Premium service and the environment on the hotel website through interaction with customers.

7. Manage the online reputation of the Premium service on the hotel website, on the Gaviota S.A. website and on social networks (Tripadvisor, Zoover, Monarc, Holidaycheck).

8. Expand the negotiations through the MINTU R with the Russian tour operators.

Task 11. Evaluation of indicators

In the operation of the Premium service until 2017, an increase per year can be seen: in 2015, with an average price of 26.95 CUC and only 6588 customers / days, an income of 177 thousand CUC was obtained; In 2016, there was a slight increase in the average price, which was 56.59 CUC, with 11421 customers / days, for a total income of 646 thousand CUC; finally, in 2017, customers / days were 13,754 with an average price of 82. 91 CUC, which allowed to obtain an income of 1140 thousand CUC, of which 494 thousand CUC over 2016, see the following table.

Table $N^{\circ}$ 4. Analysis of the Clients / Days, Income and Average Income / Customers / Days indicators

\begin{tabular}{|c|c|c|c|}
\hline Year & Customers / Days & $\begin{array}{c}\text { Entry } \\
\text { (CUC) }\end{array}$ & $\begin{array}{c}\text { Average } \\
\text { income / Customers / Days } \\
\text { (CUC) }\end{array}$ \\
\hline 2015 & 6588 & 177594.03 & 26.95 \\
\hline 2016 & 11421 & 646359.72 & 56.59 \\
\hline 2017 & 13754 & 1140435.86 & 82.91 \\
\hline
\end{tabular}

Source: Own Elaboration

A negative behavior in the marketing of the service in its first year of 2015 evolved favorably, which allowed an increase in occupancy level of 35.89\% in 2017.

Assessment of the Strategy for the marketing of the Premium service

Through the criterion of specialists, the Strategy for the marketing of the Premium Service in the Playa Pesquero hotel was evaluated, for which it was necessary:

1. Assess the level of knowledge of specialists

2. Prepare a test on the strategic lines related to the implementation actions of the product, price, distribution and promotion strategies

3. Process the results from the answers issued by the specialists.

Fifteen specialists linked to the Gaviota SA Tourism Group were selected, eight of them had a high level of knowledge, and two were of medium level, so the rest was 
discarded. The test was applied to the 10 selected specialists, for which it was only necessary to carry out a round given the high consensus reached in the five aspects consulted, thus, the proposal of the product, price, distribution and promotion strategies achieved a high relevance for $100 \%$, however, with respect to the applicability of the strategies $77 \%$ considered high the applicability and only $23 \%$ gave it an average value, among others causes, because selling all the year with the contract price without making offer is very difficult due to the changes that arise in the markets, in addition all the segments do not react in the same way, which makes it difficult to obtain the desired results in the medium term.

Among the suggested actions proposed by the specialists consulted are the following:

1. Renew the contract prices with the main tour operators with which the hotel operates (Thomas Cook, Transat and Sunwing) to sell it all year round:

2. Use the Premium section for the lodging of incentive groups with high purchasing power;

3. Develop new honeymoon and wedding packages;

4. To ensure that the Premium service is chosen by the receptive AA.VV Havanatur, Viajes Cubanacán and Gaviotatur for optional overnight stays in the territory, for clients with high purchasing power;

5. Make publications in digital media such as Caribbean News Digital;

6. Build a snack in the beach area.

The applied strategy contributes, from the Premium service, to the fulfillment of the aspects related to: the elevation of the quality of the services and the achievement of an adequate coherence in the quality / price ratio; the improvement of commercialization forms through the use of the most advanced information and communication technologies; and increased arrivals, to diversify $r$ source markets and customer segments, raising growth rates in line with that of tourism velopment.

Finally, the partial application of the strategy allowed the transformation of the problem identified in the Premium service and the achievement of favorable results in its commercialization, thus achieving a response to the identified scientific problem, so that the idea to be defended in the investigation.

\footnotetext{
"Visión de Futuro" Año 16, Volumen N²3 N², Julio - Diciembre 2019 - Pág. 274 - 293

URL de la Revista: http://visiondefuturo.fce.unam.edu.ar/index.php/visiondefuturo/index

URL del Documento: http://visiondefuturo.fce.unam.edu.ar/index.php/visiondefuturo/issue/view/16

ISSN 1668 - 8708 - Versión en Línea

E-mail: revistacientifica@fce.unam.edu.ar
} 


\section{CONCLUSION}

1. The strategy designed to market the Premium service at the Playa Pesquero hotel has four essential components: phases, objectives, tasks, and techniques to be employed. It is distinguished by including the design of the profile of the target markets, the potential of the product for those respective markets and provides tools to prepare the product, price, distribution and promotion strategies.

2. The strategy for marketing the Premium service at the Playa Pesquero hotel has five strategic lines aimed at: Identifying and working for the incorporation of customer segments in the current markets of Canada, the United Kingdom, Germany and Italy; Capture customer segments from potential markets: Russia, Poland, Austria, Chile and the United States; Identify and work for the incorporation of segments of business clients, events and diplomatic tours in Cuba and in the current markets of the hotel; and finally, Establish and sell the Premium service all year round with the contract prices with the tour operators.

3. The partial application of the strategy for the marketing of the Premium service in the Playa Pesquero hotel obtained among its fundamental results the profile design of the target markets: Canada, United Kingdom, Germany and Italy; the updating of strategic objectives; the design of product strategies, price, distribution and promotion; as well as the increase of the income of the service, which validates the idea to defend and solves the problem that generated the investigation.

\section{REFERENCES}

Please refer to articles in Spanish Bibliography.

\section{BIBLIOGRAPHCIAL ABSTRACT}

Please refer to articles Spanish Biographical abstract.

\footnotetext{
"Visión de Futuro" Año 16, Volumen Nº 23 №2, Julio - Diciembre 2019 - Pág. 274 - 293

URL de la Revista: http://visiondefuturo.fce.unam.edu.ar/index.php/visiondefuturo/index

URL del Documento: http://visiondefuturo.fce.unam.edu.ar/index.php/visiondefuturo/issue/view/16

ISSN 1668 - 8708 - Versión en Línea

E-mail: revistacientifica@fce.unam.edu.ar
} 